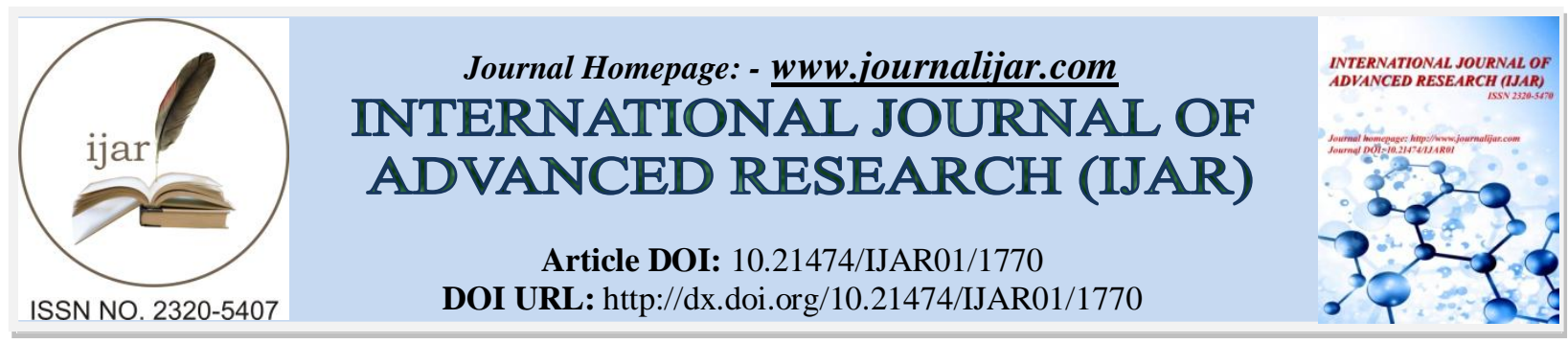

RESEARCH ARTICLE

\title{
PLASMA LEVEL OF TOTAL ANTIOXIDANT AND FREQUENCY OF HBSC, HBSS,HBAA, HBAS, HBAC AND G6PD DEFICIENCY IN ICTERIC CHILDREN PRESENTING WITH ANAEMIA.
}

Mathew Folaranmi Olaniyan* and Akerele Cletus.

Department of Medical Laboratory Science, Achievers University, Owo-Nigeria.

\section{Manuscript Info}

Manuscript History

Received: 22 August 2016

Final Accepted: 19 September 2016

Published: October 2016

Key words:-

Frequency, HbSC, HbSS,HbAA, HbAS,

HbAC, G6PD, Deficiency, Icteric

Children, Anaemia, total antioxidant

\section{Abstract}

Background:- Jaundice is a common clinical condition among anaemic children.

Aim and Objective:- This work was designed to evaluate the Plasma Level of Total Antioxidants and Frequency of HbSC, HbSS, HbAA, $\mathrm{HbAS}, \mathrm{HbAC}$ and G6PD Deficiency in Icteric Children Presenting with Anaemia.

Materials and Methods:- One hundred icteric children aged 3-12 years presenting with anaemia were recruited for this work from the General Hospital, Oka-Akoko-Ondo state.Alkaline cellulose acetate membrane haemoglobin electrophoresis was carried out on the subjects to determine the haemoglobin types while immunochromatographic technique was adopted was qualitative determination of G6PD. ELIZA techchnique was used to determine HBsAg and anti-HCV in the subjects.Cyaemethhaemoglobin method was used to determine haemoglobin concentration and capillary tube method was used to evaluate PCV.Total Antioxidantswas determined in the subjects biochemically by spectrophotometry.

Results:- The result obtained in the icteric children presenting with anaemia showed a significant reduction in the haemoglobin concentration in the icteric children with G6PD deficiency than the haemoglobin concentration and PCV value obtained in icteric children with $\mathrm{HbAS}, \mathrm{HbAC}$ and HbAA. The PCV value obtained in icteric children with G6PD deficiency was significantly higher than in $\mathrm{HbSC}$. The frequencies of G6PD deficiency and electrophoretic types in the icteric children were found to be: 40(40\%) G6PD deficiency, $28(28 \%) \mathrm{HbSC}, 30(30 \%) \mathrm{HbSS}, 2(2 \%) \mathrm{HbAS}, 2(2 \%) \mathrm{HbAC}$, and 2(2\%) HbAA respectively. While thepattern of gender distribution obtained from the study showed: Male:30(30\%) G6PD deficiency, 12(12\%)HbSC, 16(16\%) HbSS, 0(0\%) HbAS, 1(1\%) HbAC, $0(0)$ HbAA and in female: 10(10\%)G6PD deficiency, 16(16\%)HbSC, 14(14\%) HbSS, 2(2\%) HbAS, 1(1\%)HbAC and 2(2\%) HbAA. G6PD deficiency and HbSS were more pravalent in icteric male children while $\mathrm{HbAS}$ and $\mathrm{HbAA}$ were more frequent in their female counterpart.There was a significantly lower plasma value of Total antioxidant in patients $\mathrm{HbSS}, \mathrm{HbSC}$ and those with G6PD deficiency than the value obtained in subjects with $\mathrm{HbAA}, \mathrm{HbAS}$ and $\mathrm{HbAC}$ with $p<0.05$. There was a significantly lower plasma value of 
Total antioxidant in HbSS, HbSC than those with G6PD deficiency with $\mathrm{p}<0.05$.

Conclusion: G6PD deficiency, $\mathrm{HbSS}$ and $\mathrm{HbSC}$ with significant reduction in total antioxidant were more prevalent among the icteric children.

Copy Right, IJAR, 2016,. All rights reserved.

\section{Introduction:-}

Haemolysis is the premature destruction of erythrocytes. A hemolytic anemia will develop if bone marrow activity cannot compensate for the erythrocyte loss. The severity of the anemia depends on whether the onset of hemolysis is gradual or abrupt and on the extent of erythrocyte destruction (Gallagher, 2013). Mild hemolysis can be asymptomatic while the anemia in severe hemolysis can be life threatening and cause angina and cardiopulmonary decompensation. The clinical presentation also reflects the underlying cause for haemolysis (Gallagher, 2013). For example, sickle cell anemia is associated with painful occlusive crises. Hemolytic anemia has multiple causes, and the clinical presentation can differ depending on the etiology. An array of laboratory tests are available for detecting hemolysis, and specialized tests may be indicated to diagnose the cause for haemolysis. There are differences in the management of various types of hemolytic anaemias. Hemolysis can be due to hereditary and acquired disorders. The etiology of premature erythrocyte destruction is diverse and can be due to conditions such as intrinsic membrane defects, abnormal hemoglobins, erythrocyte enzymatic defects, immune destruction of erythrocytes, mechanical injury, and hypersplenism (Gallagher,2013).

Hemolysis may be an extravascular or an intravascular phenomenon. Autoimmune hemolytic anemia and hereditary spherocytosis are examples of extravascular hemolysis because the red blood cells are destroyed in the spleen and other reticuloendothelial tissues. Intravascular hemolysis occurs in hemolytic anemia due to the following: Prosthetic cardiac valves, Glucose-6-phosphate dehydrogenase (G6PD) deficiency, Thrombotic thrombocytopenic purpura, Disseminated intravascular coagulation, Transfusion of ABO incompatible blood and Paroxysmal nocturnal hemoglobinuria (PNH) (Gallagher,2013).

Hemolysis may also be intramedullary, when fragile red blood cell (RBC) precursors are destroyed in the bone marrow prior to release into the circulation. Intramedullary hemolysis occurs in pernicious anemia and thalassemia major. Hemolysis is associated with a release of RBC lactate dehydrogenase (LDH). Hemoglobin released from damaged RBCs leads to an increase in indirect bilirubin and urobilinogenlevels(Packman and Leddy,1995; Glader, 1999; Beutl et al.,2010; Gallagher,2013 ).

A patient with mild hemolysis may have normal hemoglobin levels if increased RBC production matches the rate of RBC destruction. However, patients with mild hemolysis may develop marked anemia if their bone marrow erythrocyte production is transiently shut off by viral (parvovirus B-19) or other infections. This scenario would be an aplastic crisis since the bone marrow can no longer compensate for ongoing hemolysis.Skull and skeletal deformities can occur in childhood due to a marked increase in hematopoiesis and resultant bone marrow expansion in disorders such as thalassemia(Packman and Leddy,1995; Glader, 1999; Beutl et al.,2010; Gallagher,2013 ).

A wide range of causes of hemolytic anemia have been documented. Only the more commonly encountered hemolytic disorders are discussed in this article.Recent articles have noted that intravenous immunoglobulin $G$ (IVIG) therapy given during pregnancy, the contrast medium iomeprol, and mitral valve replacement can cause hemolysis(Packman and Leddy,1995; Glader, 1999; Beutl et al.,2010; Gallagher,2013 ).

Hereditary disorders may cause hemolysis as a result of erythrocyte membrane abnormalities, enzymatic defects, and hemoglobin abnormalities. Hereditary disorders include the following: Glucose-6-phosphate dehydrogenase (G6PD) deficiency, Hereditary spherocytosis, Sickle cell anemia; Acquired causes of hemolysis include the following; Immune disorders, Toxic chemicals and drug, Antiviral agents (eg, ribavirin ), Physical damage and Infections. Autoimmune hemolytic anemia (AIHA) can be due to warm or cold autoantibody types and, rarely, mixed types. Most warm autoantibodies belong to the immunoglobulin IgG class. These antibodies can be detected by a direct Coombs test, which also is known as a direct antiglobulin test (DAT). AIHA may occur after allogeneic hematopoietic stem cell transplantation. The 3-year cumulative incidence in this population has been reported at 4.44\%.(Packman and Leddy,1995; Glader, 1999; Beutl et al.,2010; Gallagher,2013 ). 
The antioxidant defense system has many components. A deficiency in any of these components can cause a reduction in the overall antioxidant status of an individual. Reduction in total antioxidant status has been implicated in several disease states, such as cancer and heart disease. Antioxidants play an important role in preventing the formation of and scavenging of free radicals and other potentially toxic oxidizing species. There are three categories of antioxidant species: enzyme systems (GSH reductase, catalase, peroxidase, etc.), small molecules (ascorbate, uric acid, GSH, vitamin E, etc.) and proteins (albumin, transferrin, etc.). Different antioxidants vary in their reducing power (Stanneret al.,2004;Csepregiet al.,2016;).

Justification:-

Haemolyticanaemia is a common cause of death in children.Little has been reported about the aetiology of the cause of this fatal health illness in Oka-Akoko, Ondo state-Nigeria hence the need for this work in the area.

\section{Aim and Objective:-}

This work was designed to evaluate thePlasma Level of Total Antioxidants and Frequency of HbSC, HbSS, HbAA, $\mathrm{HbAS}, \mathrm{HbAC}$ and G6PD Deficiency in Icteric Children Presenting with Anaemia

\section{Methodology:-}

Materials:-

Study area:-

This work was carried out in Oka- Akoko which is in the Northern part of Ondo state that shares border with Kogi and Edo State in Nigeria.

\section{Study Population:-}

One hundred anaemic icteric children aged 3 to 12 years in Oka-Akoko classified using electrophoretic pattern and G6PD screening were investigated. The HbSS and HbSC studied were recruited from General Hospital, Oka-Akoko when in crisis.

\section{Inclusion criteria:-}

1. Only anaemic icteric children were investigated

2. Children who are not HbsAg and anti-HCV positive were recruited for the work

3. Children free from Plasmodium spp infection were recruited for the work.

\section{Exclusion criteria:-}

1. Anaemic but anicteric children were excluded from the work

2. Children who are HbsAg and anti-HCV positive were not recruited for the work

3. Children with Plasmodium spp infection were not recruited for the work.

4. Patients on antimalaria drugs were excluded

\section{Biological specimen:-}

Five mililitres of Venous Whole blood sample sample was obtained from each of the subjects and preserved in EDTA bottles for analysis.

\section{Methods:-}

Haemoglobin electrophoresis and Plasmodium spp detection:-

Haemoglobin electrophoresis for haemoglobin electrophoretic pattern and Plasmodium spp detection using Giemsa thick film techniquewere carried out as described by Cheesbrough, (2002).

\section{Qualitative Detection of G6PD using CareStart $^{\mathrm{TM}}$ G6PD Rapid Diagnostic Test:-}

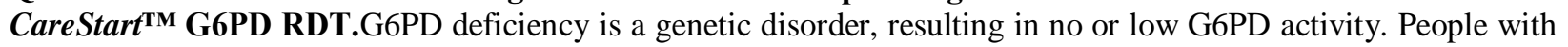
G6PD deficiency should not take primaquine, an antimalarial drug, and other drugs with high oxidative stress because it could cause serious side effects such as acute hemolysis.

\section{Determination of HbsAg and Anti-HCV:-}

These were carried out by ELIZA using reagent kit of BIORAD. 


\section{Evaluation of Total Antioxidants:-}

The Total Antioxidants was evaluated in the subjects using RANDOX kit.

Principle:- ABTS ${ }^{\circledR}$ (2, 2'-Azino-di-[3-ethylbenzthiazoline sulphonate]) is incubated with a peroxidase (metmyoglobin) and $\mathrm{H} 2 \mathrm{O} 2$ to produce the radical cation $\mathrm{ABTS}^{\circledR}{ }^{*}+$. This has a relatively stable blue-green color, which is measured at $600 \mathrm{~nm}$. Antioxidants in the added sample cause suppression of this color production to a degree which is proportional to their concentration.

Identification of Plasmodium spp in the subjects:-

This was carried out by Giemsa-Thick film technique

\section{Data analysis:-}

The information obtained was subjected to statistical analysis using SPSS 17.0 to determine mean, standard deviation and level of significance of the differences at 0.05 using student's ' $t$ ' test.

\section{Ethical consideration:-}

The proposal of this work was first presented to the Research and Ethical committee of the General Hospital, OkaAkoko-Nigeria. The proposal was carefully reviewed and approved before sample collection.

\section{Results:-}

The overall frequency of G6PD deficiency, HbSC, HbSS , HbAS, HbAC and HbAA, obtained in this work among the icteric children include : 40(40\%), 28(28\%), $30(30 \%), 2(2 \%), 2(2 \%)$, and $2(2 \%)$ respectively. While the pattern of gender distribution obtained from the study showed: Male:30(30\%) G6PD deficiency, 12(12\%)HbSC, 16(16\%) HbSS, $0(0 \%) \mathrm{HbAS}, \quad 1(1 \%) \quad \mathrm{HbAC}, 0(0 \%)$ HbAAand in female: 10(10\%)G6PD deficiency, 16(16\%) HbSC, 14(14\%) HbSS, 2(2\%) HbAS, $1(1 \%) \mathrm{HbAC}$ and 2(2\%) HbAA. G6PD deficiency and $\mathrm{HbSS}$ were more pravalent in icteric male children while $\mathrm{HbAS}$ and $\mathrm{HbAA}$ were more frequent in their female counterpart (Tables 1,2,3,4 and figure 1,2,3).

The results obtained showed a significantly lower PCV value in icteric children with G6PD deficiency than the results obtained from icteric children with $\mathrm{HbSC}, \mathrm{HbAS}, \mathrm{HbAC}$ and $\mathrm{HbAA}(\mathrm{p}<0.05)$ (Tables 1,2,3,4 and Figure1). there was also a significantly lower PCV value in HbSC and HbSS compared with the results obtained in ictric children with $\mathrm{HbAS}, \mathrm{HbAC}$ and $\mathrm{HbAA}() \mathrm{p}<0.05)$ (Tables 1,2,3 and Figure1). No significant difference was obtained in the value of PCV in icteric children with G6PD deficiency compared with icteric children with HbSS; HbSC compared with $\mathrm{HbSS}$; HbAS compared with $\mathrm{HbAA}, \mathrm{HbAC}$ and in icteric children with $\mathrm{HbAC}$ compared with $\operatorname{HbAA}(\mathrm{p}>0.05)$ (Tables 1,2,3,4 and Figure1). There was no significant difference in the haemoglobin concentration obtained in icteric children with G6PD deficiency compared with HbSS, HbSC; HbSC compared with HbSS; HbAS compared with $\mathrm{HbAC}, \mathrm{HbAA}$ and $\mathrm{HbAC}$ compared with $\mathrm{HbAA}(\mathrm{p}>0.05)$ (Tables 1,2,3 and Figure1). However, there was a significantly lower haemoglobin concentration in the results obtained from icteric children who lack G6PD than the icteric children with $\mathrm{HbAS}, \mathrm{HbAC}, \mathrm{HbAA}(\mathrm{p}<0.05)$ (Tables $1,2,3$ and Figure1). A significantly lower in $\mathrm{HbSS}$ and $\mathrm{HbSC}$ than icteric children with $\mathrm{HbAS}, \mathrm{HbAC}$ and $\mathrm{HbAA}(\mathrm{p}<0.05)$ (Tables 1,2,3 and Figure1).

There was a significantly lower plasma value of Total antioxidant in patients $\mathrm{HbSS}$, HbSC and those with G6PD deficiency than the value obtained in subjects with HbAA, HbAS and HbAC with $\mathrm{p}<0.05$ (Tables 1,2,3,4). There was a significantly lower plasma value of Total antioxidant in HbSS, HbSC than those with G6PD deficiency with $\mathrm{p}<0.05$ (Tables $1,2,3,4$ ).

However, there was no significant difference in the plasma value of Total antioxidant subjects with HbSC compared $\mathrm{HbSS}$; HbAS compared with $\mathrm{HbAC}$; HbAS compared HbAA and HbAA compared with HbAC with $\mathrm{p}>0.05$ (Table $1,2,3$, ). 
Table 1:- OverallFrequency, Mean and standard deviation of the electrophoretic pattern, PCV and haemoglobin concentration obtained in icteric children presenting with anaemia

\begin{tabular}{|l|l|l|l|l|l|l|}
\hline & $\begin{array}{l}\text { G6PD } \\
\text { DEFICIENCY }\end{array}$ & HbSC & HbSS & HbAS & HbAC & HbAA \\
\hline Frequency & $40(40 \%)$ & $28(28 \%)$ & $30(30 \%)$ & $2(2 \%)$ & $2(2 \%)$ & $2(2 \%)$ \\
\hline PCV/\% & $9 \pm 2.0$ & $16 \pm 1.0$ & $12 \pm 3.0$ & $39 \pm 3.0$ & $40 \pm 0$ & $42 \pm 0$ \\
\hline Hb/g/dl & $4 \pm 0.5$ & $6 \pm 1.0$ & $5 \pm 0.5$ & $13 \pm 2.0$ & $14 \pm 0$ & $14 \pm 0$ \\
\hline $\begin{array}{l}\text { Total } \\
\text { Antioxidant/ } \mathbf{\mu M}\end{array}$ & $410 \pm 10.0$ & $360 \pm 9.0$ & $340 \pm 10.0$ & $561 \pm 7.0$ & $568 \pm 8.0$ & $570 \pm 5.0$ \\
\hline
\end{tabular}

Table 2:- Gender distributionof theFrequency of G6PD deficiency, HbSC, HbSS， HbAS， HbAC and HbAA obtained in icteric children

\begin{tabular}{|l|l|l|l|l|l|l|}
\hline & G6PD DEFICIENCY & HbSC & HbSS & HbAS & HbAC & HbAA \\
\hline Frequency & $40(40 \%)$ & $28(28 \%)$ & $30(30 \%)$ & $2(2 \%)$ & $2(2 \%)$ & $2(2 \%)$ \\
\hline Male & $30(30 \%)$ & $12(12 \%)$ & $16(16 \%)$ & $0(0 \%)$ & $1(1 \%)$ & $0(0)$ \\
\hline Female & $10(10 \%)$ & $16(16 \%)$ & $14(14 \%)$ & $2(2 \%)$ & $1(1 \%)$ & $2(2 \%)$ \\
\hline
\end{tabular}

Table 3:- Comparative analysis of the Mean and standard deviation of the PCV and haemoglobin concentration obtained in icteric children with G6PD deficiency and anaemic icteric children with $\mathrm{HbSC}, \mathrm{HbSS}, \mathrm{HbAS}, \mathrm{HbAC}$ and $\mathrm{HbAA}$

\begin{tabular}{|c|c|c|c|c|c|c|c|}
\hline & & $\begin{array}{l}\text { G6PD } \\
\text { DEFICIENC } \\
\text { Y } \\
\text { Vs.HbSC }\end{array}$ & $\begin{array}{l}\text { G6PD } \\
\text { DEFICIENC } \\
\text { Y } \\
\text { Vs. HbSS }\end{array}$ & $\begin{array}{l}\text { G6PD } \\
\text { DEFICIENC } \\
\text { Y } \\
\text { Vs. HbAS }\end{array}$ & $\begin{array}{l}\text { G6PD } \\
\text { DEFICIENC } \\
\text { Y } \\
\text { Vs. HbAC }\end{array}$ & $\begin{array}{l}\text { G6PD } \\
\text { DEFICIENC } \\
\text { Y } \\
\text { Vs. HbAA }\end{array}$ & $\begin{array}{l}\text { HbSC } \\
\text { VsHbS } \\
\text { S }\end{array}$ \\
\hline \multirow[t]{3}{*}{ PCV } & ' $t$ ' & -3.13 & -0.83205 & -9.21425 & -14.31 & -16.5 & 1.27 . \\
\hline & 'p' & 0.044 & 0.247 & 0.0058 & 0.0024 & 0.002 & 0.17 \\
\hline & Comment & $\mathrm{P}<0.05^{*}$ & $p>0.05$ & $\mathrm{P}<0.05^{*}$ & $\mathrm{P}<0.05^{*}$ & $\mathrm{P}<0.05^{*}$ & $p>0.05$ \\
\hline \multirow[t]{3}{*}{ Hb } & 't' & $\begin{array}{l}-1.79 \\
\end{array}$ & -1.41 & -4.37 & -20 & -20 & 0.89 \\
\hline & 'p' & 0.11 & 0.147 & 0.024 & 0.0013 . & 0.0012 & 0.23 \\
\hline & Comment & $p>0.05$ & $p>0.05$ & $\mathrm{P}<0.05^{*}$ & $\mathrm{P}<0.05^{*}$ & $\mathrm{P}<0.05^{*}$ & $p>0.05$ \\
\hline \multirow{2}{*}{$\begin{array}{c}\text { Total } \\
\text { Antioxida } \\
\text { nt } \\
\end{array}$} & 't' & 3.71647 & 4.95 & -12.37 & -12.34 & -14.31 & 1.49 \\
\hline & 'p' & 0.03269 & 0.019238 . & 0.003236 & 0.003253 & 0.0024 & 0.14 \\
\hline comment & & $\mathrm{P}<0.05^{*}$ & $\mathrm{P}<0.05^{*}$ & $\mathrm{P}<0.05^{*}$ & $\mathrm{P}<0.05^{*}$ & $\mathrm{P}<0.05^{*}$ & $P>0.05$ \\
\hline
\end{tabular}

Table 4:- Comparative analysis of the results obtatained from icteric children with icteric children with $\mathrm{HbSC}$, $\mathrm{HbSS}, \mathrm{HbAS}, \mathrm{HbAC}$ and $\mathrm{HbAA}$

\begin{tabular}{|c|c|c|c|c|c|c|c|c|c|c|}
\hline & & $\begin{array}{c}\text { HbSC } \\
\text { VsHbAS }\end{array}$ & $\begin{array}{c}\text { HbSC } \\
\text { VsHbAC }\end{array}$ & $\begin{array}{c}\text { HbSC } \\
\text { VsHbAA }\end{array}$ & $\begin{array}{c}\text { HbAS } \\
\text { VsHbAC }\end{array}$ & $\begin{array}{c}\text { HbAS } \\
\text { VsHbAA }\end{array}$ & $\begin{array}{c}\text { HbAC } \\
\text { VsHbAA }\end{array}$ & $\begin{array}{c}\text { HbSS } \\
\text { VsHbAS }\end{array}$ & $\begin{array}{c}\text { HbSS } \\
\text { VsHbAC }\end{array}$ & $\begin{array}{c}\text { HbSS } \\
\text { VsHbA } \\
\text { A }\end{array}$ \\
\hline \multirow{3}{*}{$\mathrm{PCV} / \%$} & ' $t$ ' & -8.36 & -17.68 & -26. & 0.93 & -1.4. & -1. & -6.79 & -9.171 & -10 \\
\hline & 'p' & 0.01 . & 0.002 & 0.001 & 0.23 & 0.148 & 0.211. & 0.011 & 0.0058 & 0.005 \\
\hline & $\begin{array}{c}\text { Comm } \\
\text { ent }\end{array}$ & $\mathrm{P}<0.05^{*}$ & $\mathrm{P}<0.05^{*}$ & $\mathrm{P}<0.05^{*}$ & $p>0.05$ & $\mathrm{p}>0.05$ & $p>0.05$ & $\mathrm{P}<0.05^{*}$ & $\mathrm{P}<0.05^{*}$ & $\mathrm{P}<0.05^{*}$ \\
\hline \multirow[t]{3}{*}{$\mathrm{Hb} / \mathrm{g} / \mathrm{dl}$} & 't' & -3.13 & -8 . & -8. & -0.5 . & -0.5 . & 0 & -3.88 & -18. & -18. \\
\hline & 'p' & 0.04 & 0.008 & 0.008 & 0.333 & 0.333 & 0 & 0.030 & 0.002 & 0.002 \\
\hline & $\underset{\mathrm{nt}}{\text { Comme }}$ & $\mathrm{P}<0.05^{*}$ & $\mathrm{P}<0.05^{*}$ & $\mathrm{P}<0.05^{*}$ & $\mathrm{p}>0.05$ & $\mathrm{p}>0.05$ & $\mathrm{p}>0.05$ & $\mathrm{P}<0.05^{*}$ & $\mathrm{P}<0.05^{*}$ & $\mathrm{P}<0.05^{*}$ \\
\hline \multirow{2}{*}{$\begin{array}{c}\text { Total } \\
\text { antioxid } \\
\text { ant }\end{array}$} & 't' & -17.63 & -17.71 & -20.40 & -0.66 & -1.05 & -0.21 & -18.11 & -17.80 & -20.57 \\
\hline & 'p' & 0.002 & 0.002 & 0.0012 & 0.29 & 0.20 & 0.43 & 0.002 & 0.002 & 0.0012 \\
\hline $\begin{array}{l}\text { commen } \\
\mathrm{t}\end{array}$ & & $\mathrm{P}<0.05^{*}$ & $\mathrm{P}<0.05^{*}$ & $\mathrm{P}<0.05^{*}$ & $\mathrm{P}>0.05$ & $\mathrm{P}>0.05$ & $\mathrm{P}>0.05$ & $\mathrm{P}<0.05^{*}$ & $\mathrm{P}<0.05^{*}$ & $\mathrm{P}<0.05^{*}$ \\
\hline
\end{tabular}




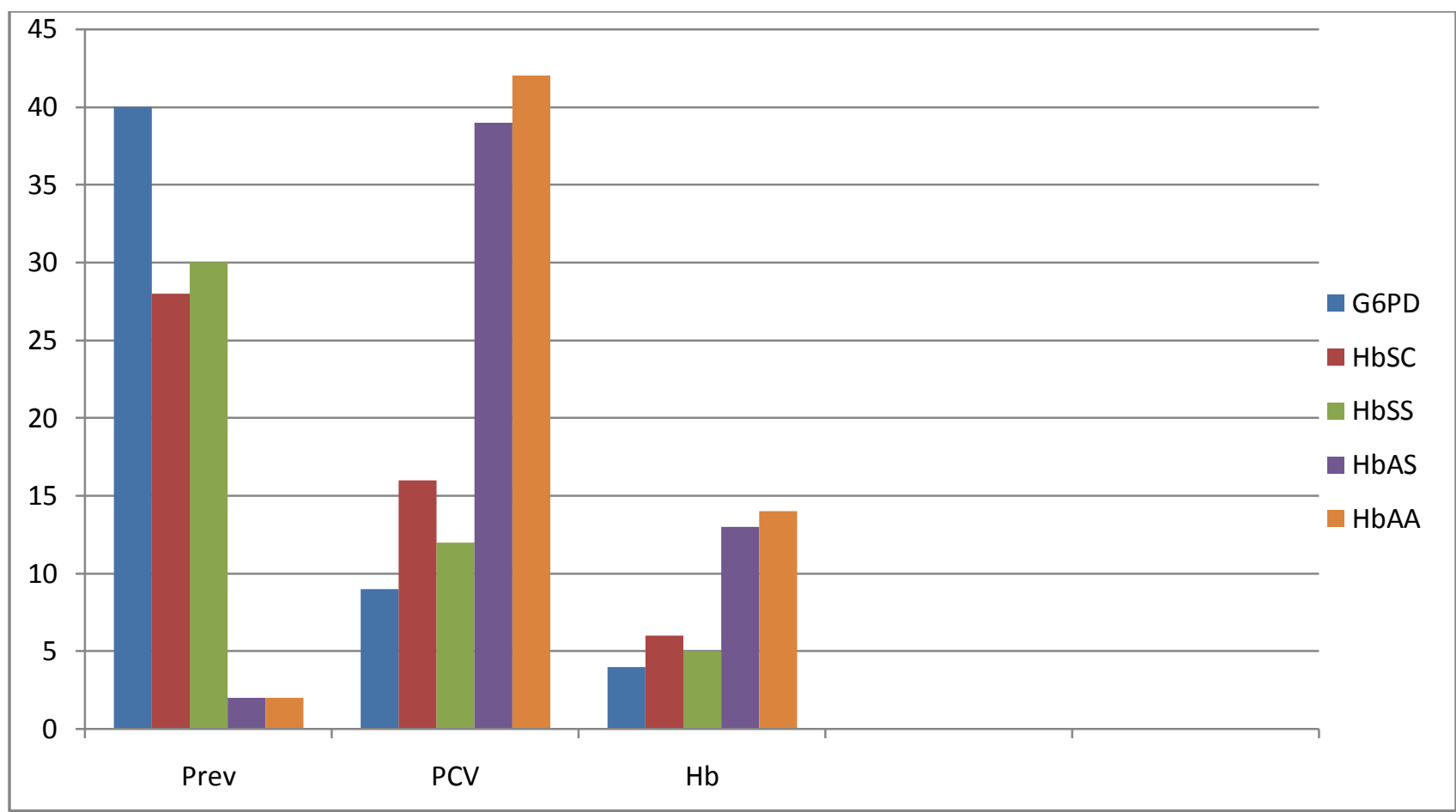

Figure 1:- Comparative analysis of the results obtatained from icteric children with G6PD deficiency, HbSC, HbSS, HbAS, HbAC and HbAA.

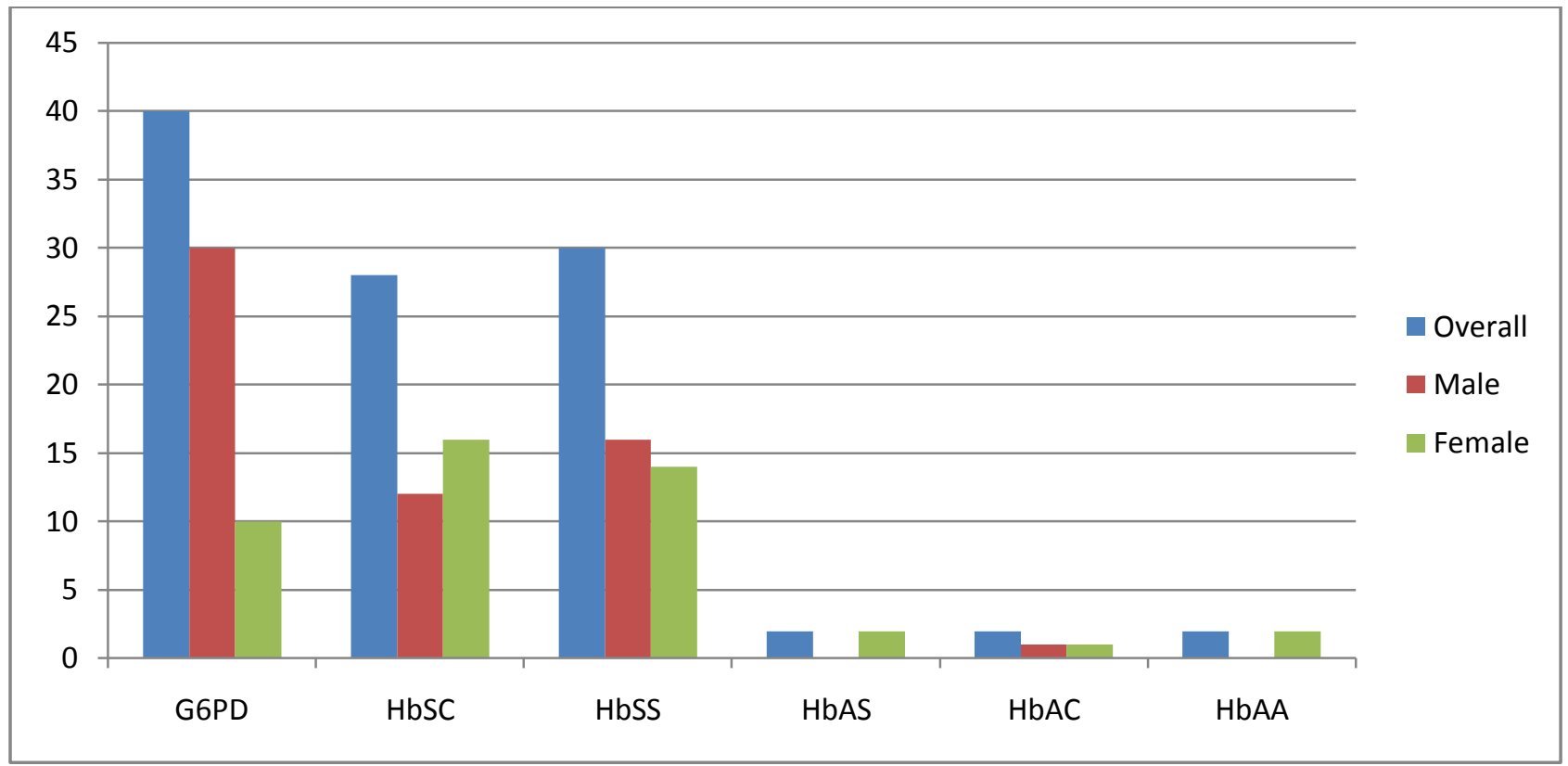

Figure 2:- Gender distribution of G6PD deficiency, $\mathrm{HbSC}, \mathrm{HbSS}, \mathrm{HbAS}, \mathrm{HbAC}$ and $\mathrm{HbAA}$ in icteric children. 


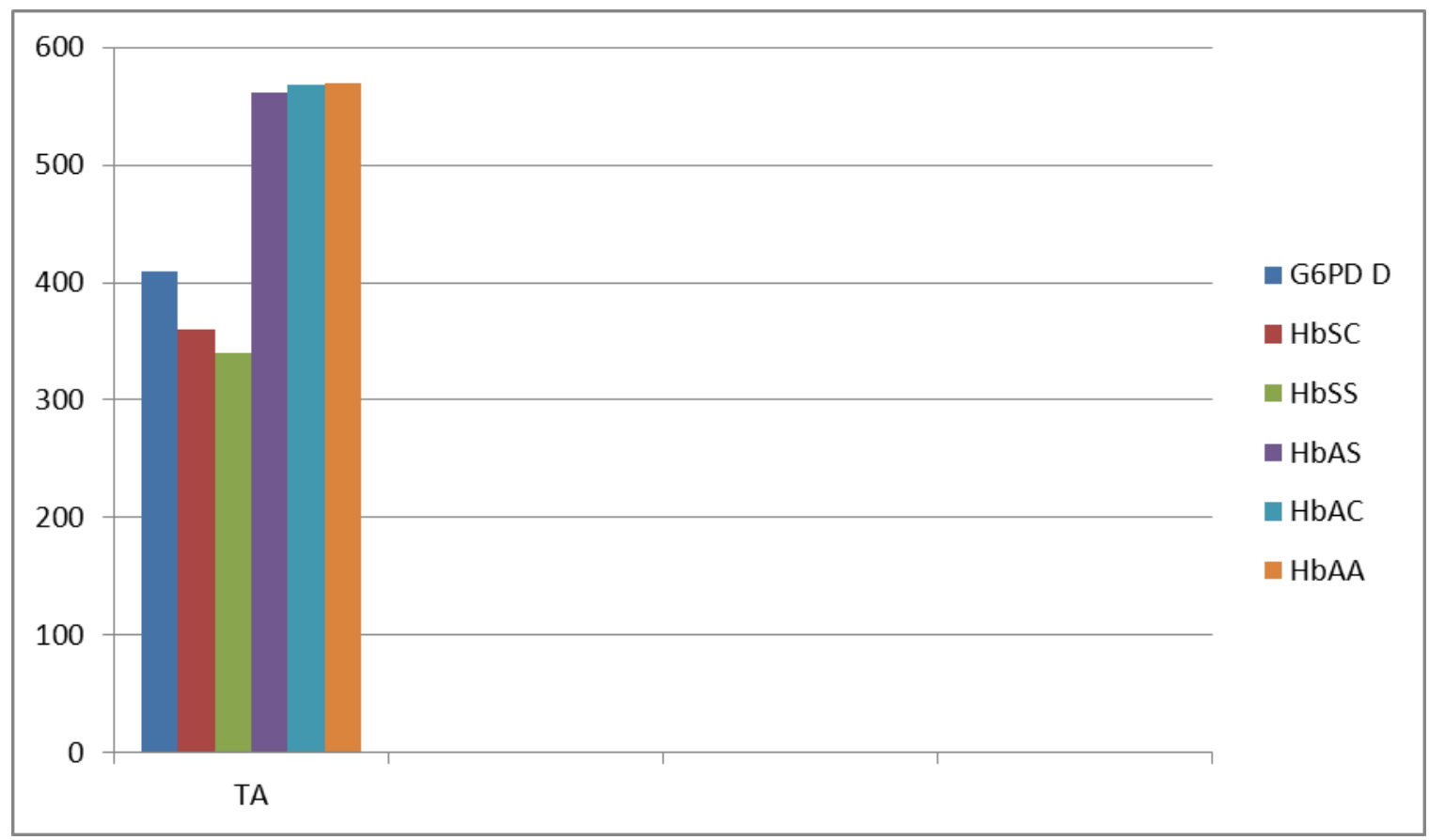

Key: TA - Total antioxidant; G6PD D - G6PD deficiency

Figure 3:- Showing comparative plasma level of Total antioxidant in the subjects.

\section{Discussion, conclusion and recommendation:- \\ Discussion:-}

The overall frequency of G6PD deficiency, HbSC, $\mathrm{HbSS}$, HbAS, HbAC and HbAA, obtained in this work among the icteric children include : 40(40\%), 28(28\%), $30(30 \%), \quad 2(2 \%), 2(2 \%), \quad$ and $2(2 \%)$ respectively. While the pattern of gender distribution obtained from the study showed: Male:30(30\%) G6PD deficiency, $\quad 12(12 \%) \mathrm{HbSC}, 16(16 \%) \mathrm{HbSS}, 0(0 \%) \mathrm{HbAS}, \quad 1(1 \%) \quad \mathrm{HbAC}, 0(0) \mathrm{HbAA}$ and in female: 10(10\%)G6PD deficiency, 16(16\%)HbSC, 14(14\%) HbSS, 2(2\%) HbAS, $1(1 \%) \mathrm{HbAC}$ and 2(2\%) HbAA. G6PD deficiency and HbSS were more pravalent in icteric male children while HbAS and HbAA were more frequent in their female counterpart.The frequency of distribution of $28 \% \mathrm{HbSC}$ and $30 \% \mathrm{HbSS}$ found among the icteric study as indicated above was higher than the report of Nubilaet al., (2013)that found HbSS (5.5\%) and HbSC $(1.1 \%)$ among Yorubas in Ibadan, south western Nigeria in a pilot study and SCD frequency of $2.39 \%$. reported by Nwogohet al., (2012) in Benin City, South-South Nigeria.

These differences could be attributed to the fact that haemolyticanaemia is associated with HbSS and HbSC which was the major inclusion criteria for the recruitment of test subjects for this work. In addition all HbSS and HbSC icteric children were studied during crisis which accelerates massive haemolysis of red blood cells (Serjeant, 1997; Serjeant and Serjeant,2001; Madigan and Malik, 2006; Lal and Vinchinsky, 2011; Nwogohet al., 2012 ; Serjeant, 2013) leading to decreased PCV and haemoglobin concentration.

The results obtained showed a significantly lower PCV and haemoglobin concentration in icteric children with G6PD deficiency than the results obtained from icteric children with $\mathrm{HbAS}, \mathrm{HbAC}$ and $\mathrm{HbAA}$ and in the value of PCV in G6PD deficiency than in icteric children with HbSC. This could be attributed to the fact that Hereditary disorders may cause hemolysis as a result of erythrocyte membrane abnormalities, enzymatic defects, and hemoglobin abnormalities such as Glucose-6-phosphate dehydrogenase (G6PD) deficiency, HbSS and $\mathrm{HbSC}($ Gallagher,2010). These findings with respect to G6PD deficiency do not agree with the report of Williams et al.,2013 that there was not association between vital parameters or hematocrit and G6PD deficiency but in agreement with their report that history of scleral icterus may increase the odds of G6PD deficiency, though did not exclude other common causes of icterus such as sickle cell disease or malarial infection. 
G6PD deficiency was found to be more frequent in male than female icteric children. This finding agrees with the report of Williams et al.,2013 who found that the overall frequency of G6PD deficiency was $15.3 \%$ (24.1\% in males, 6.6\% in females). In addition G6PD deficiency is inherited as an X-linked recessive disorder. G6PD deficiency is polymorphic, with more than 300 variants(Nkhoma et al., 2009; Olusanyaet al., 2015).

The frequency of G6PD deficiency(40\%) found in this work among the icteric children in Oka-Akoko was lower than the frequency rate of $43 \%$ found among children presenting with jaundice in Ilorin, Nigeria by Amiwero and Olatunji, (2012). They reported that children in the age group one day to 15 years presenting with jaundice at Ilorin have an overall 43.0 percent [males (50 percent) and females (28.1 percent) chance of having G6PD deficiency, as the underlying cause of their jaundice and that this justifies the need for G6PD screening in children presenting with jaundice.

There was also a significantly lower PCV and haemoglobinconcentration in HbSC and HbSS compared with the results obtained in ictric children with $\mathrm{HbAS}, \mathrm{HbAC}$ and $\mathrm{HbAA}$. The significant reduction in the haemoglobin concentration and PCV obtained in icteric children withHbSS, HbSC and G6PD deficiencyin this study could be attributed to haemolyticanaemia associated with enzymopathy( G6PD deficiency) and the genetic defect (HbSS and $\mathrm{HbSC}$ ). Their pathophysiology is characterized by massive red blood destruction which usually lead to reduced RBC count, haemoglobin concentration and PCV which was also reported in this work. HbSS and HbSC contains sickling haemoglobin types which include $\mathrm{HbS}$ and $\mathrm{HbC}$. These could greatly be responsible for the reduction in PCV and haemoglobin concentration found among the icteric children studied(Serjeant, 1997; Serjeant and Serjeant,2001; Madigan and Malik, 2006; Lal and Vinchinsky, 2011; Nwogohet al., 2012; Serjeant, 2013).

There was a significantly lower plasma value of Total antioxidant in patients $\mathrm{HbSS}$, HbSC and those with G6PD deficiency than the value obtained in subjects with $\mathrm{HbAA}, \mathrm{HbAS}$ and HbAC. There was a significantly lower plasma value of Total antioxidant in HbSS, HbSC than those with G6PD deficiency.This significant reduction in total antioxidant could be associated with oxidative stress induced by the crisis associated with the clinical condition and also as a result of massive destruction of red blood cells causing over utilization of antioxidants to reduce the cellular damage because antioxidant molecule inhibits the oxidation of other molecules. Oxidation is a chemical reaction that can produce free radicals, leading to chain reactions that may damage cells.Oxidative stress can be considered as either a cause or consequence of some diseases (Stanneret al., 2004; Dabelsteinet al.,2007) .

\section{Conclusion:-}

The result revealed a significant reduction in the haemoglobin concentration and PCV in the icteric children with G6PD deficiency than the haemoglobin concentration and PCV value obtained in icteric children with HbAS, $\mathrm{HbAC}$ and HbAA. The PCV value obtained in icteric children with G6PD deficiency was significantly higher than in $\mathrm{HbSC}$. The frequencies of G6PD deficiency and electrophoretic types in the icteric children were found to be: 40(40\%) G6PD deficiency, 28(28\%) HbSC, 30(30\%) HbSS, 2(2\%) HbAS, 2(2\%) HbAC, and 2(2\%) HbAA respectively. While the pattern of gender distribution obtained from the study showed: Male:30(30\%) G6PD deficiency, $\quad 12(12 \%) \mathrm{HbSC}, 16(16 \%) \mathrm{HbSS}, 0(0 \%) \mathrm{HbAS}, 1(1 \%) \mathrm{HbAC}, \quad 0(0) \mathrm{HbAA}$ and in female: 10(10\%)G6PD deficiency, 16(16\%)HbSC, 14(14\%) HbSS, 2(2\%) HbAS, $\quad 1(1 \%) \mathrm{HbAC}$ and 2(2\%) HbAA. G6PD deficiency and HbSS were more pravalent in icteric male children while HbAS and HbAA were more frequent in their female counterpart. Total antioxidant was lower in subjects with HbSS, HbSC, G6PD deficiency than in subjects with $\mathrm{HbAS}, \mathrm{HbAC}$ and $\mathrm{HbAA}$.

\section{Recommendation:-}

Routine investigation of children with jaundice ( haemolyticanaemia ) should includehaemoglobin electrophoresis, determination of G6PD and evaluation of total antioxidant for effecyive management

\section{List of Refrences:-}

1. Adu-Gyasi D, Asante KP, Newton S, Dosoo D, Amoako S, (2015).Evaluation of the diagnostic accuracy of CareStart G6PD deficiency Rapid Diagnostic Test (RDT) in a malaria endemic area in Ghana, Africa.PLoS One.. 10 (4):e0125796. [Medline].

2. Amiwero C. E. and Olatunji P. O. (2012) Frequency of G6PD deficiency in children presenting with jaundice in Ilorin, Nigeria. International Journal of Biomedical and Health Sciences ;Vol. 8, No. 1, 0794-4748/2012 
3. B. Nwogoh, A. S. Adewoyin, O. E. Iheanacho, and G. N. Bazuaye (2012), "Frequency of haemoglobin variants in Benin City, Nigeria," Annals of Biomedical Sciences, vol. 11, no. 2, pp. 60-64,. View at Google Scholar

4. Baird JK, Dewi M, Subekti D, Elyazar I, Satyagraha AW (2015). Noninferiority of glucose-6-phosphate dehydrogenase deficiency diagnosis by a point-of-care rapid test vs the laboratory fluorescent spot test demonstrated by copper inhibition in normal human red blood cells. Transl Res. Jun. 165 (6):677-88. [Medline].

5. Beutler E (1991). Glucose-6-phosphate dehydrogenase deficiency.N Engl J Med. Jan 17. 324(3):169-74. [Medline].

6. Beutler E (1994). G6PD deficiency.Blood. Dec 1. 84(11):3613-36. [Medline].

7. Beutler E (2008). Glucose-6-phosphate dehydrogenase deficiency: a historical perspective. Blood. Jan 1. 111(1):16-24. [Medline].

8. Beutler E, Bull BS, Herrmann PC (2010) Hemolytic Anemia Resulting from Chemical and Physical Agents.Kaushansky K, Lichtman MA, Beutler E, Kipps TJ, Seligsohn U, Prchal JT, eds. Williams Hematology. 8th ed. New York, NY: McGraw Hill; 2010. 763-68.

9. Beutler E, Westwood B, Prchal JT, Vaca G, Bartsocas CS, Baronciani L (1992). New glucose-6-phosphate dehydrogenase mutations from various ethnic groups.Blood. Jul 1. 80(1):255-6. [Medline].

10. Beutler E.(2006), "Disorders of haemoglobin structure: sickle cell anaemia and related abnormalities," in Williams Haematology, M. A. Lichtman and W. J. Williams, Eds., vol. 47, pp. 667-700, McGraw-Hill, New York, NY, USA. View at Google Scholar

11. Bhutani VK, Poland R, Meloy LD, Hegyi T, Fanaroff AA, Maisels MJ (2016).Clinical trial of tin mesoporphyrin to prevent neonatal hyperbilirubinemia.J Perinatol.Mar 3. 27 (9):884-9. [Medline].

12. Boretti FS, Buehler PW, D'Agnillo F, et al. (2009). "Sequestration of extracellular hemoglobin within a haptoglobin complex decreases its hypertensive and oxidative effects in dogs and guinea pigs". The Journal of Clinical Investigation 119 (8): 2271-80. doi:10.1172/JCI39115. PMC 2719941.PMID 19620788.

13. Bosman GJ, Willekens FL, Werre JM (2005). "Erythrocyte aging: a more than superficial resemblance to apoptosis?".Cellular Physiology and Biochemistry 16 (1-3): 1-8. doi:10.1159/000087725. PMID 16121027.

14. Bratosin D, Mazurier J, Tissier JP, et al. (February 1998). "Cellular and molecular mechanisms of senescent erythrocyte phagocytosis by macrophages.A review".Biochimie80 (2): 173-95.doi:10.1016/S03009084(98)80024-2. PMID 9587675.

15. Csepregi, K; Neugart, S; Schreiner, M; Hideg, Éva.(2016) "Comparative Evaluation of Total Antioxidant Capacities of Plant Polyphenols". Molecules. 21 (2): 208. doi:10.3390/molecules21020208. PMID 26867192.

16. Dabelstein W, Reglitzky A, Schütze A, Reders K (2007). "Automotive Fuels".Ullmann's Encyclopedia of Industrial Chemistry. doi:10.1002/14356007.a16_719.pub2. ISBN 3-527-30673-0.

17. Fasola F., Adedapo K., Anetor J., and Kuti M. (2007), "Total antioxidants status and some hematological values in sickle cell disease patients in steady state," Journal of the National Medical Association, vol. 99, no. 8, pp. 891-894. View at Google Scholar · View at Scopus

18. Fleming A. F., Storey J., Molineaux L., Iroko E. A., and Attai E. D. (1979), “Abnormal haemoglobins in the Sudan savanna of Nigeria. I. Frequency of haemoglobins and relationships between sickle cell trait, malaria and survival," Annals of Tropical Medicine and Parasitology, vol. 73, no. 2, pp. 161-172.View at Google Scholar . View at Scopus

19. Frank JE (2005). Diagnosis and management of G6PD deficiency. Am Fam Physician. 2005 Oct 1. 72(7):127782. [Medline].

20. Gallagher PG (2010) The Red Blood Cell Membrane and Its Disorders: Hereditary Spherocytosis, Elliptocytosis, and Related Diseases. Kaushansky K, Lichtman MA, Beutler E, Kipps TJ, Seligsohn U, Prchal JT, eds. Williams Hematology. 8th ed. New York, NY: McGraw Hill; 617-46.

21. Gallagher PG (2013). Red cell membrane disorders. Hoffman R, Benz EJ Jr, Silberstein LE, Heslop H, Weitz J, Anastasi J, eds. Hematology: Basic Principles and Practice. 6th ed. New York, NY: Churchill Livingstone; 592-613.

22. GladerBE (1999) Hemolytic anemia in children. Clin Lab Med. 19(1):87-111, vi. [Medline].

23. Herrick J. B. (1910), "Peculiar elongated and sickle-shaped red blood corpuscles in a case of severe anemia," Archives of Internal Medicine, vol. 6, no. 5, pp. 517-521,. View at Publisher · View at Google Scholar

24. HortonJ. A. B., The Diseases of Tropical Climates and Their Treatment, Churchill, London, UK, 1874

25. Hsieh M. M., Tisdale J. F., and Rodgers G. P. (2013), "Haemolyticanaemia: thalassemias and sickle cell disorders," in The Bethesda Handbook of Clinical Haematology, G. P. Rodgers and N. S. Young, Eds., vol. 4, pp. 37-56, Lippincott Williams \& Wilkins, Philadelphia, Pa, USA, 3rd edition, View at Google Scholar

26. Kaplan M, Hammerman C (2004). Glucose-6-phosphate dehydrogenase deficiency: a hidden risk for kernicterus. SeminPerinatol. Oct. 28(5):356-64. [Medline]. 
27. Kaplan M, Hammerman C, Vreman HJ, Stevenson DK, Beutler E (2001). Acute hemolysis and severe neonatal hyperbilirubinemia in glucose-6-phosphate dehydrogenase-deficient heterozygotes.J Pediatr. Jul. 139(1):13740. [Medline].

28. Lal A. and Vinchinsky E. P.( 2011), "Sickle cell disease," in Postgraduate Haematology, A. V. Hoffbrand, D. Catovsky, E. G. D. Tuddenham, and A. R. Green, Eds., vol. 7, pp. 109-125, Blackwell Publishing, 6th edition. View at Google Scholar

29. Luzzatto L, Nannelli C, Notaro R. (2016 ) Glucose-6-Phosphate Dehydrogenase Deficiency. HematolOncolClin North Am. Apr. 30 (2):373-93. [Medline].

30. Madigan C. and Malik P. (2006), "Pathophysiology and therapy for haemoglobinopathies; Part I: sickle cell disease," Expert Reviews in Molecular Medicine, vol. 8, no. 9, pp. 1-23. View at Publisher · View at Google Scholar · View at Scopus

31. Maisels MJ, Bhutani VK, Bogen D, Newman TB, Stark AR, Watchko JF (2009). Hyperbilirubinemia in the newborn infant > or $=35$ weeks' gestation: an update with clarifications. Pediatrics. Oct. 124 (4):1193-8. [Medline].

32. Manganelli G, Masullo U, Passarelli S, Filosa S (2013). Glucose-6-phosphate dehydrogenase deficiency: disadvantages and possible benefits. CardiovascHematolDisord Drug Targets. Mar 1. 13(1):73-82. [Medline].

33. Manjurano A, Sepulveda N, Nadjm B, Mtove G, Wangai H, Maxwell C (2015), African glucose-6-phosphate dehydrogenase alleles associated with protection from severe malaria in heterozygous females in Tanzania. PLoS Genet. Feb. 11 (2):e1004960. [Medline].

34. McDade J, Abramova T, Mortier N, Howard T, Ware RE (2008). A novel G6PD mutation leading to chronic hemolytic anemia.Pediatr Blood Cancer. Dec. 51(6):816-9. [Medline].[Full Text].

35. Mesner O, Hammerman C, Goldschmidt D, Rudensky B, Bader D, Kaplan M (2004). Glucose-6-phosphate dehydrogenase activity in male premature and term neonates. Arch Dis Child Fetal Neonatal Ed. Nov. 89(6):F555-7. [Medline].[Full Text].

36. Minucci A, Giardina B, Zuppi C, Capoluongo E (2009). Glucose-6-phosphate dehydrogenase laboratory assay: How, when, and why?.IUBMB Life. Jan. 61(1):27-34. [Medline].

37. Modell B. and Darlison M. (2008) "Global epidemiology of haemoglobin disorders and derived service indicators," Bulletin of the World Health Organization, vol. 86, no. 6, pp. 480-487. View at Publisher · View at Google Scholar · View at Scopus

38. Modell B., Ed., Guidelines for the Control of Haemoglobin Disorders, WHO, Sardinia, Italy, 1989.

39. Murki S, Dutta S, Narang A, Sarkar U, Garewal G. A randomized, triple-blind, placebo-controlled trial of prophylactic oral phenobarbital to reduce the need for phototherapy in G6PD-deficient neonates.J Perinatol. 2005 May. 25(5):325-30. [Medline].

40. Nantakomol D, Paul R, Palasuwan A, Day NP, White NJ, Imwong M (2013). Evaluation of the phenotypic test and genetic analysis in the detection of glucose-6-phosphate dehydrogenase deficiency. Malar J. Aug 21. 12(1):289. [Medline].[Full Text].

41. Nkhoma E.T, Poole C, Vannappagari V, Hall SA, Beutler E. The global frequency of glucose-6-phosphate dehydrogenase deficiency: a systematic review and meta-analysis. Blood Cells Mol Dis. 2009 May-Jun. 42(3):267-78. [Medline].

42. Nubila T, Ukaejiofo EO, Nubila NI, Azeez R. (2013) Frequency distribution of hemoglobin variants among Yorubas in Ibadan, south western Nigeria: A pilot study. Niger J ExpClin Biosci;1:39-42

43. Odièvre M.H., Verger E., Silva-Pinto A. C., and Elion J. (2011), "Pathophysiological insights in sickle cell disease," Indian Journal of Medical Research, vol. 134, no. 10, pp. 532-537. View at Google Scholar · View at Scopus

44. Okwi A. L. Byarugaba W., Ndugwa C. M., Parkes A., Ocaido M., and J. K. Tumwine (2010), "An up-date on the frequency of sickle cell trait in Eastern and Western Uganda," BMC Blood Disorders, vol. 10, article 5, View at Publisher · View at Google Scholar · View at PubMed · View at Scopus

45. Olusanya B.O, Osibanjo FB, Slusher TM (2015). Risk factors for severe neonatal hyperbilirubinemia in low and middle-income countries: a systematic review and meta-analysis. PLoS One.. 10 (2):e0117229. [Medline].

46. Oo NN, Bancone G, Maw LZ, Chowwiwat N, Bansil P, Domingo GJ 2016,. Validation of G6PD Point-of-Care Tests among Healthy Volunteers in Yangon, Myanmar.PLoS One.. 11 (4):e0152304. [Medline].[Full Text].

47. OzbayHosnut F, Ozcay F, SeldaBayrakci U, Avci Z, Ozbek N 2008). Etiology of hemolysis in two patients with hepatitis A infection: glucose-6-phosphate dehydrogenase deficiency or autoimmune hemolytic anemia. Eur J Pediatr. Dec. 167(12):1435-9. [Medline].

Packman CH, Leddy JP (1995) Acquired hemolytic anemia due to warm-reacting autoantibodies.Beutler E, Lichtman MA, Coller BS, Kipps TJ, eds. Williams Hematology. 5th ed. New York, NY: McGraw Hill; 667-84. 
48. Peters AL, Van Noorden CJ (2009). Glucose-6-phosphate dehydrogenase deficiency and malaria: cytochemical detection of heterozygous G6PD deficiency in women. J HistochemCytochem. Nov. 57(11):1003-11. [Medline].[Full Text].

49. Piel F. B., Patil A. P., Howes R. E., (2013) "Global epidemiology of Sickle haemoglobin in neonates: a contemporary geostatistical model-based map and population estimates," The Lancet, vol. 381, no. 9861, pp. 142-151, View at Publisher · View at Google Scholar · View at Scopus

50. Prchal JT, Gregg XT (2005). Red Cell Enzymes.Hematology/ASH Education Book.Available at http://asheducationbook.hematologylibrary.org/content/2005/1/19.full?sid=5fb34610-c164-4deb-9e850922086efaea.Accessed: April 6, 2016.

51. Roseff S. D.(2009), "Sickle cell disease: a review," Immunohematology, vol. 25, no. 2, pp. 67-74,. View at Google Scholar · View at Scopus

52. Rosse W. F., Narla M., Petz L. D., and Steinberg M. H. (2000), "New views of sickle cell disease pathophysiology and treatment," Haematatogy, vol. 2000, no. 1, pp. 2-17.View at Google Scholar

53. Samanta S, Kumar P, Kishore SS, Garewal G, Narang A (2009). Donor blood glucose 6-phosphate dehydrogenase deficiency reduces the efficacy of exchange transfusion in neonatal hyperbilirubinemia. Pediatrics. Jan. 123(1):e96-e100. [Medline].

54. SerjeantG. R (1997), "Sickle-cell disease," The Lancet. vol. 350, no. 9079, pp. 725-730,. View at Publisher . View at Google Scholar · View at Scopus

55. Serjeant G. R.andSerjeant B. E.( 2001), "The epidemiology of sickle cell disorder: a challenge for Africa," Archives of Ibadan Medicine, vol. 2, no. 2, pp. 46-52. View at Publisher · View at Google Scholar

56. Serjeant G. R. (2013), "The natural history of sickle cell disease," Cold Spring Harbor Perspectives in Medicine, vol. 3, no. 10, Article ID a011783,. View at Publisher • View at Google Scholar · View at PubMed . View at Scopus

57. Stanner SA, Hughes J, Kelly CN, Buttriss (J2004). "A review of the epidemiological evidence for the 'antioxidant hypothesis'". Public Health Nutrition., 7 (3): 407-22. doi:10.1079/PHN2003543. PMID 15153272.

58. Stephen J. McPhee, Maxine A. Papadakis (2009)Current Medical Diagnosis and Treatment 2009 page 436

59. Uzoegwu P. N. andOnwurah A. E. (2003), "Frequency of haemoglobinopathy and malaria diseases in the population of old Aguata Division, Anambra State, Nigeria," Biokemistri, vol. 15, no. 2, pp. 57-66,. View at Google Scholar

60. Valaes T, Drummond GS, Kappas A (1998).Control of hyperbilirubinemia in glucose-6-phosphate dehydrogenase-deficient newborns using an inhibitor of bilirubin production, Snmesoporphyrin.Pediatrics.May. 101(5):E1. [Medline].

61. Valiaveedan S, Mahajan C, Rath GP, Bindra A, Marda MK.( 2011 ) Anaesthetic management in patients with glucose-6-phosphate dehydrogenase deficiency undergoing neurosurgical procedures. Indian J Anaesth. Jan. 55(1):68-70. [Medline].[Full Text].

62. Wang FL, Boo NY, Ainoon O, Wong MK (2009). Comparison of detection of glucose-6-phosphate dehydrogenase deficiency using fluorescent spot test, enzyme assay and molecular method for prediction of severe neonatal hyperbilirubinaemia. Singapore Med J. Jan. 50(1):62-7. [Medline].

63. Westerman M., Pizzey A., Hirschman J. (2008), "Microvesicles in haemoglobinopathies offer insights into mechanisms of hypercoagulability, haemolysis and the effects of therapy," British Journal of Haematology, vol. 142, no. 1, pp. 126-135. View at Publisher · View at Google Scholar · View at PubMed · View at Scopus

64. WHO Regional office for Africa, Sickle cell disease prevention and control, 2013, http://www.afro.who.int/en/nigeria/nigeria-publications/1775-sickle cell disease.html.

65. Williams O1, Gbadero D, Edowhorhu G, Brearley A, Slusher T, Lund TC(2013) Glucose-6-phosphate dehydrogenase deficiency in Nigerian children.PLoS One. 2013 Jul 12;8(7):e68800. doi: 10.1371/journal.pone.0068800. Print 2013.

66. World Health Organisation 2008, "Management of haemoglobin disorders," in Proceedings of the Report of Joint WHO-TIF Meeting, Nicosia, Cyprus, November 2007.

67. Yang Y, Li Z, Nan P, Zhang X (2011). Drug-induced glucose-6-phosphate dehydrogenase deficiency-related hemolysis risk assessment.ComputBiol Chem. Jun. 35(3):189-92. [Medline]. 